\title{
Reconsideration of Classical Antibiotic Lincomycin: Anti-inflammatory Effect in LPS-stimulated RAW 264.7 Cells
}

\author{
Eun-Jin Yang ${ }^{\dagger}$, Nari Lee ${ }^{\dagger}$, and Chang-Gu Hyun* \\ Department of Chemistry and Cosmetics, Jeju National University, Jeju 63243, Republic of Korea
}

Received: February 20, 2020 / Revised: March 22, 2020 / Accepted: March 26, 2020

\begin{abstract}
Since, side effects of antibiotics are frequently emphasized these days, their use is gradually diminishing, and alternative drugs are being developed. We have sought to reintroduce them as raw materials for human health as conventional 'weapons' that have been retired after their historical duties. In this study, we investigated the anti-inflammatory effects of lincomycin (LIN), on lipopolysaccharide (LPS)-stimulated RAW 264.7 cells. Our findings show that LIN potently inhibited production of LPS-induced proinflammatory mediators, such as nitric oxide (NO) and prostaglandin $\mathrm{E}_{2}\left(\mathrm{PGE}_{2}\right)$, without cytotoxicity. Consistent with these findings, LIN strongly decreased protein expression levels of inducible NO synthase (iNOS) and cyclooxygenase (COX-2). Furthermore, LIN reduced pro-inflammatory cytokines such as tumor necrosis factor (TNF)- $\alpha$, interleukin (IL)-6, and IL-1ß. To further elucidate the mechanisms of these inhibitory effects of LIN, we studied LPS-induced IKB- $\alpha$ degradation, and mitogen-activated protein kinase (MAPK) phosphorylation. LIN suppressed downregulation of inhibitory $\kappa B$ (IкB- $\alpha$ ) degradation, and the phosphorylation of the c-Jun N-terminal kinase (JNK) pathway. Based on these results, we suggest that LIN may be considered a potential candidate as an anti-inflammatory cosmetic or a medicine for human health.
\end{abstract}

Keywords: Lincomycin, antibiotic, inflammatory, nitric oxide, RAW 264.7

\section{Introduction}

Inflammation is one of the most important mechanisms in defending the body from tissue damage and pathogen infiltration. Normal inflammation reduces the expression of pro-inflammatory proteins, and increases the expression of anti-inflammatory ones [1-3]. Chronic inflammation may develop into inflammatory diseases such as Parkinson's disease, cancer, rheumatoid arthritis, and atherosclerosis, as well as allergic diseases such

\section{*Corresponding author}

Tel: +82-64-720-2350, Fax: +82-64-720-2331

E-mail: cghyun@jejunu.ac.kr

${ }^{\dagger}$ These authors contributed equally to this work.

○ 2020, The Korean Society for Microbiology and Biotechnology as skin diseases and bronchial asthma, so appropriate treatment is needed [4-6]. During the inflammatory process, inducible nitric oxide synthase (iNOS) and COX-2 expression induces excessive amounts of $\mathrm{NO}$ and $\mathrm{PGE}_{2}$, as well as pro-inflammatory cytokines such as IL-6, IL$1 \beta$, and TNF- $\alpha$ [7-9].

Expression of pro-inflammatory cytokines is regulated by NF- $\kappa \mathrm{B}$ and MAPKs $[10,11]$. NF- $\mathrm{kB}$ plays an important role in the expression of genes involved in immune and inflammatory responses. In the absence of stimulation, $\mathrm{NF}-\mathrm{\kappa B}$ is present in the cytoplasm in an inactive form associated with I $\kappa B-\alpha$. However, in the case of stimulation such as by LPS, IкB is phosphorylated by IкB kinase (Ikk), and degraded by proteosome activity, and liberated NF- $\mathrm{kB}$ translocates to the nucleus and induces 


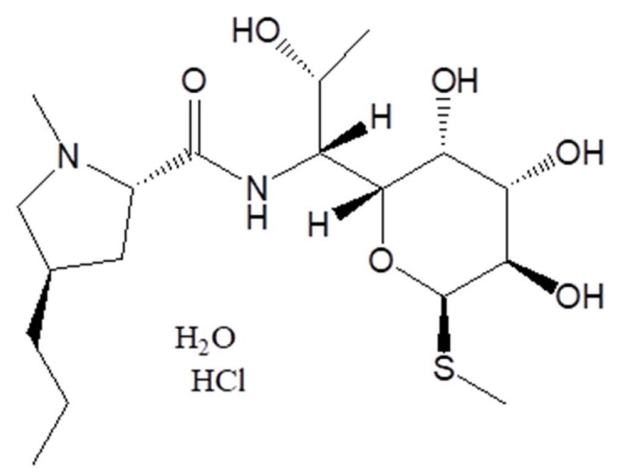

Fig. 1. Chemical structure of lincomycin (LIN).

the expression of target genes, such as various inflammatory mediators [12-14]. The three major MAPKs, namely the extracellular signal-regulated kinases (ERK1/2), c-Jun N-terminal kinase (JNK) and mitogenactivated protein (MAP p38), regulate the production of pro-inflammatory mediator phosphorylating transcription factors, including NF- $\mathrm{kB}$ and AP-1 (c-Fos and c-Jun) [15-17].

Antibiotics are antimicrobial drugs used for the treatment and prevention of pathogenic bacterial infections, which produce microorganisms and inhibit the grown of other microorganisms. Lincomycin (Fig. 1) is a lincosamide antibiotic derived from the actinomycete Streptomyces lincolnensis. It is effective against microorganisms, including some species of mycoplasma and plasmodium. However, currently, it is rarely used due to side effects and toxicity, and is only used for patients with allergies or bacterial resistance to penicillin [1820].

Previous studies have shown that some fluoroquinolone and macrolide antibiotics affect monocytes and neutrophils, which are discussed as being associated with immune processes [21]. In particular, Lincosamidebased antibiotic Clindamycin is a derivative of lincomycin, and previous studies have demonstrated antiinflammatory efficacy in monocyte THP-1 cells stimulated with LPS as well as antibacterial activity [22].

However, studies on anti-inflammatory efficacy against lincomycin have not been conducted. Therefore, we focused on the fact that classical antibiotics such as lincomycin are rarely utilized, and confirmed the antiinflammatory activity using mouse macrophages in order to explore new approaches. In this study, we inves- tigated the inhibitory effect of lincomycin on the inflammatory response in RAW 264.7 cells induced by LPS. Furthermore, the underlying molecular mechanisms of the anti-inflammatory activity of LIN were investigated.

\section{Materials and Methods}

\section{Chemicals and reagents}

Lincomycin was purchased from TCI (Tokyo Chemical Industry, Japan; Fig. 1), LPS and Griess reagent (G4410) were purchased from Sigma-Aldrich Chemical Co. (USA). Antibodies against iNOS were purchased from Millipore (Temecula, USA); COX-2 was obtained from BD Biosciences (USA); phospho-JNK, JNK and IкB- $\alpha$ were supplied by Cell Signaling Technology (USA); and $\beta$-actin was purchased from Santa Cruz Biotechnology (USA). Ammonium pyrrolidinedithiocarbamate (PDTC : NF-kB inhibitor) and SP600125 (JNK inhibitor) was purchased from Sigma-Aldrich and Cayman Chemical (USA), respectively.

\section{Cell line and culture}

Mouse monocyte RAW 264.7 cells were obtained from the Korean Cell Line Bank (KCLB) and cultured in Dulbecco's modified Eagle's medium (DMEM; Gibco, USA) supplemented with $10 \%$ fetal bovine serum (FBS; Merck Millipore, Germany) and 1\% penicillin/streptomycin in an atmosphere of $5 \% \mathrm{CO}_{2}$ at $37^{\circ} \mathrm{C}$.

\section{Cell viability assay}

3-(4,5-dimethylthiazol-2yl)-, 5-diphenyltetra-zolium bromide (MTT) was used to assess cell viability. RAW 264.7 cells were seeded in 24 -well plates for $18 \mathrm{~h}$, followed by treatment with various concentrations of lincomycin. After $24 \mathrm{~h}$ of incubation, MTT was added to each well, and the formazan crystals were dissolved in dimethyl sulfoxide (DMSO). Absorbance was measured at $540 \mathrm{~nm}$ with a microplate reader (Tecan Trading AG, Austria).

\section{Nitric oxide (NO) assay}

The culture supernatant was mixed with the same volume of Griess reagent, incubated at room temperature $\left(22-25^{\circ} \mathrm{C}\right)$ for $10 \mathrm{~min}$, and then the optical absorbance at $540 \mathrm{~nm}$ was determined with a microplate reader. The NO concentration was measured by comparison to a 
standard curve generated by serial dilution of sodium nitrite.

\section{Measurement of $\mathrm{PGE}_{\mathbf{2}}$ and pro-inflammatory cytokines}

RAW 264.7 cells were seeded in 24-well plates and incubated with or without LPS $(1 \mu \mathrm{g} / \mathrm{ml})$ in the absence or presence of various concentrations of lincomycin $(0.9$, 1.4, and $1.8 \mathrm{mM}$ ) for $24 \mathrm{~h}$. Cell culture supernatants were assayed for PGE (Abcam, USA), IL-6, IL-1 $\beta$ and TNF- $\alpha$ using ELISA kits (R\&D Systems, USA), according to the manufacturer's instructions.

\section{Western blot analysis}

Western blotting was performed using the NuPAGE electrophoresis system from Invitrogen (USA). The cells were washed twice with cold PBS, and then lysed in lysis buffer (RIPA buffer, 1\% Nonidet P-40, 1\% protease inhibitor cocktail). The cell lysates were centrifuged at $21,055 \times \mathrm{g}$ at $4^{\circ} \mathrm{C}$ for $15 \mathrm{~min}$. Protein concentration was determined using a BCA assay kit (Thermo Scientific, USA). Then, $30 \mu \mathrm{g}$ of extracted proteins was separated on $4-12 \%$ Bis-Tris NuPAGE gels and transferred to nitrocellulose membranes. Membranes were blocked with $5 \%$ skim milk for $2 \mathrm{~h}$, and then incubated overnight at $4{ }^{\circ} \mathrm{C}$ with a $1: 1000$ dilution of the primary antibody. After washing 4 times, the membranes were incubated for $30 \mathrm{~min}$ at RT with a 1:5000 dilution of HRP-conjugated secondary antibody. The membrane proteins were detected using an ECL Western Blotting Detection System (Biosesang, Korea).

\section{Statistical analysis}

Cell viability and ELISA experiments were repeated at least four times, and each experiment was performed in quadruplicate. All data are presented as mean \pm standard deviation (SD). ${ }^{*} p<0.05$ and ${ }^{* *} p<0.01$ were considered statistically significant.

\section{Results}

\section{Effect of LIN on NO production and the viability of RAW264.7 cells}

LPS significantly induced $\mathrm{NO}$ and $\mathrm{PGE}_{2}$ production in RAW 264.7 cells. Thus, we evaluated $\mathrm{NO}$ and $\mathrm{PGE}_{2}$ released into the culture supernatant by use of Griess reagent and ELISA. LPS and LIN were not added to the control (-). NO production was decreased 27.7\%, 54.1\%, and $74.5 \%$ by LIN, and $\mathrm{PGE}_{2}$ production was inhibited $48.2 \%, 67.8 \%$, and $82.6 \%$, respectively, but did not induce cytotoxicity (Figs. 2 and 3). These results also revealed that lincomycin-based anti-inflammatory studies are appropriate at concentrations of 0.9 to $1.8 \mathrm{mM}$.

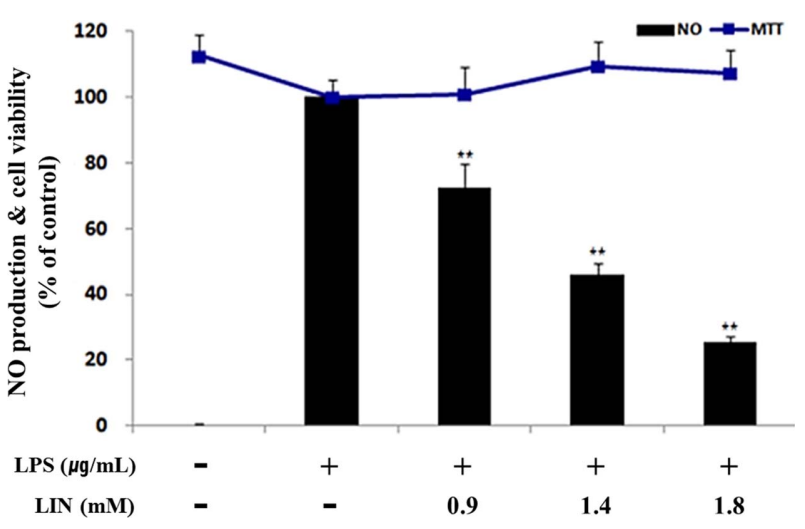

Fig. 2. Effect of lincomycin on nitric oxide production in LPS-stimulated RAW 264.7 cells. Cells were stimulated with $1 \mu \mathrm{g} / \mathrm{ml}$ of LPS only, or with LPS plus various concentrations $(0.9,1.4$, or $1.8 \mathrm{mM})$ of lincomycin for $24 \mathrm{~h}$. Nitric oxide production was determined by the Griess reagent method. Cell viability was determined after $24 \mathrm{~h}$ culture of cells stimulated with LPS in the presence of lincomycin. The data represent the mean \pm SD of quadruplicate experiments. ${ }^{*} p<0.05,{ }^{* *} p<0.01$ versus LPS alone. $I C_{50}=1.31 \mathrm{mM}$

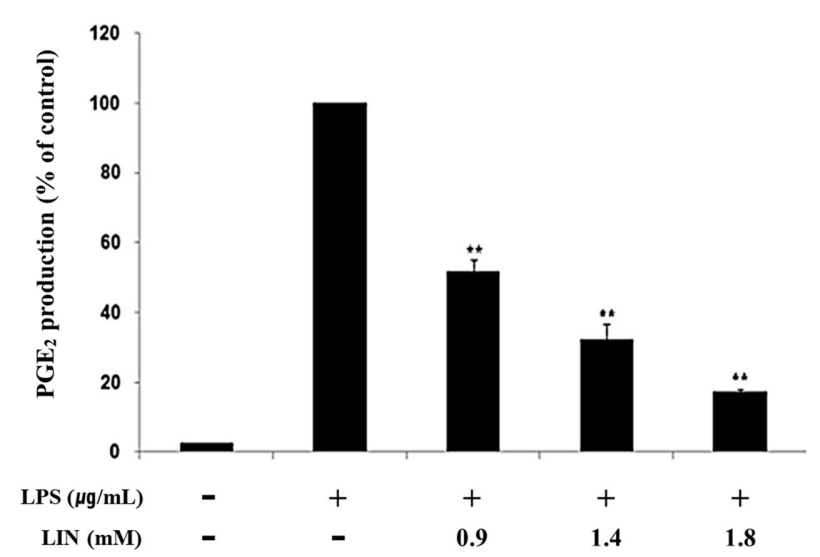

Fig. 3. Effect of on lincomycin on $\mathrm{PGE}_{2}$ production in LPSstimulated RAW 264.7 cells. Cells were stimulated with $1 \mu \mathrm{g} /$ $\mathrm{ml}$ of LPS only, or with LPS plus various concentrations $(0.9,1.4$, or $1.8 \mathrm{mM}$ ) of lincomycin for $24 \mathrm{~h}$. $\mathrm{PGE}_{2}$ production was determined by ELISA. The data represent the mean \pm SD of quadruplicate experiments. ${ }^{*} p<0.05,{ }^{* *} p<0.01$ versus LPS alone. $\mathrm{IC}_{50}=0.93 \mathrm{mM}$ 


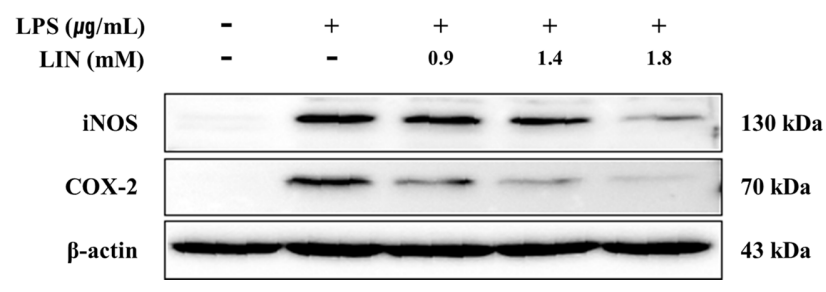

Fig. 4. Effect of lincomycin on protein levels of iNOS and COX-2 in LPS-stimulated RAW $\mathbf{2 6 4 . 7}$ cells. RAW 264.7 cells $\left(6.0 \times 10^{5}\right.$ cells $\left./ \mathrm{ml}\right)$ were stimulated with LPS $(1 \mu \mathrm{g} / \mathrm{ml})$ in the presence of lincomycin $(0.9,1.4$, or $1.8 \mathrm{mM})$ for $24 \mathrm{~h}$. Whole-cell lysates $(30 \mu \mathrm{g})$ were prepared, and the proteins were subjected to $10 \%$ SDS-PAGE. Expression of iNOS, COX-2, and $\beta$-actin were determined by western blotting. $\beta$-actin served as a loading control.

\section{Effect of LIN on the iNOS and COX-2 expression in RAW264.7 cells}

Western blotting was performed to determine whether $\mathrm{NO}$ and $\mathrm{PGE}_{2}$ production were related to iNOS and COX-2 protein expression. LPS markedly induced iNOS and COX-2 protein levels, whereas treatment with LIN inhibited such protein expression. These results indicated that the inhibition of LPS-induced $\mathrm{NO}$ and $\mathrm{PGE}_{2}$ production was due to reduced levels of iNOS and COX-2 (Fig. 4).

\section{Effect of LIN on the expression of pro-inflammatory cyto- kines in RAW264.7 cells}

Pro-inflammatory cytokines play a role in the regulation of immune and inflammatory responses in the body. LPS-stimulated macrophages produce TNF- $\alpha$, and secreted TNF- $\alpha$ or LPS induces the production of IL-6 and IL-1 $\beta$, thereby sustaining the inflammatory response. TNF- $\alpha$ promotes the onset of the inflammatory response and sustained production leads to chronic inflammation. In addition, IL-6 acts on the acute immune response, and IL- $1 \beta$ is an important cytokine in the initiation of inflammatory response to bacterial infection [23-25].

The effect of LIN on the production of pro-inflammatory cytokines IL- 6 , IL- $1 \beta$, and TNF- $\alpha$ produced by LPSstimulated RAW 264.7 cells was analyzed by ELISA. LPS stimulation increased IL-6, IL-1 $\beta$, and TNF- $\alpha$ production. IL- 6 and IL- $1 \beta$ secretion were significantly decreased by LIN in a dose dependent manner, and TNF- $\alpha$ was slightly decreased (Fig. 5A, 5B, 5C). In particular, inhibition with the higher dose of $1.8 \mathrm{mM}$ of
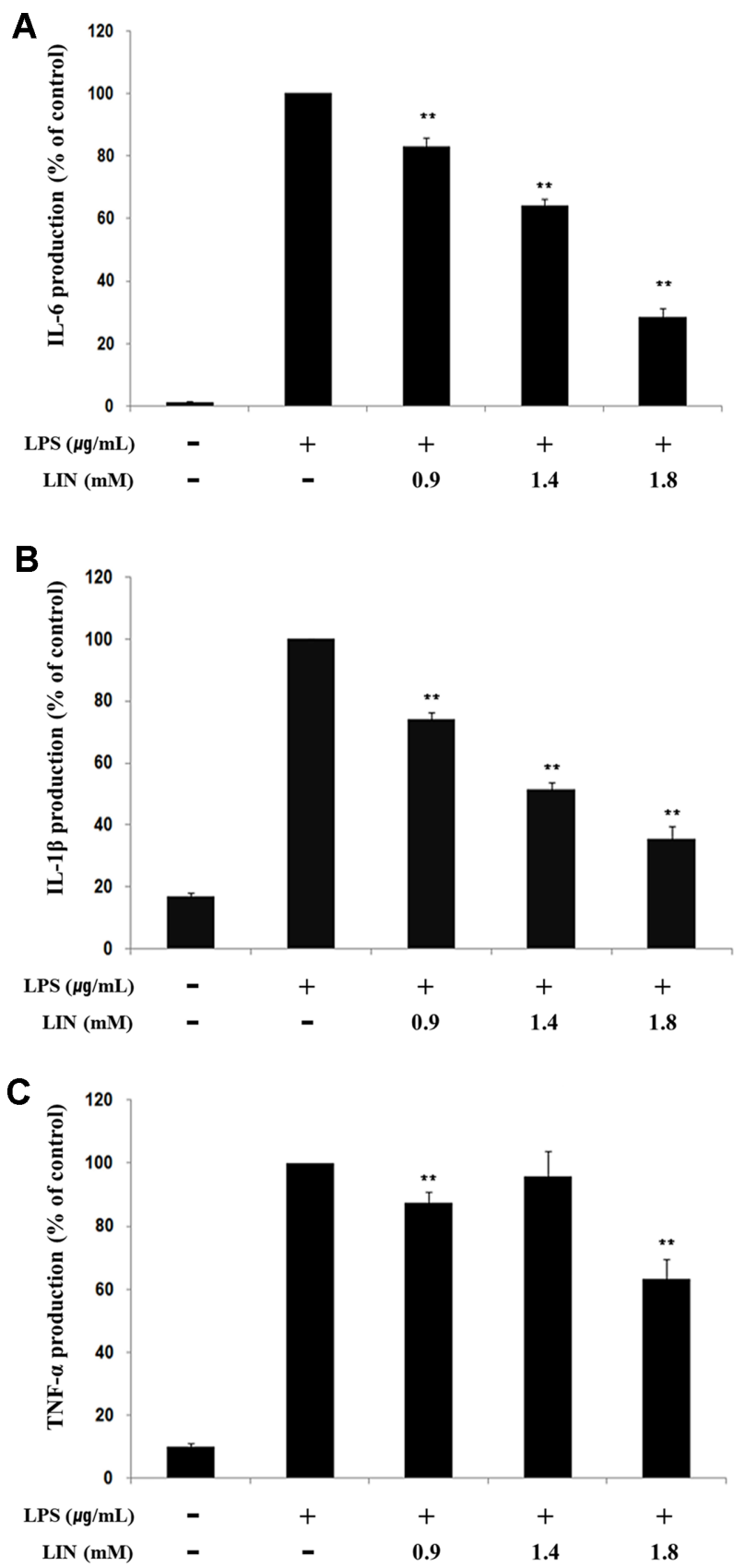

Fig. 5. Effect of lincomycin on IL-6, IL-1 $\beta$, and TNF- $\alpha$ production in LPS-stimulated RAW $\mathbf{2 6 4 . 7}$ cells. Cells were stimulated with $1 \mu \mathrm{g} / \mathrm{ml}$ of LPS only, or with LPS plus various concentrations $(0.9,1.4$, or $1.8 \mathrm{mM})$ of lincomycin for $24 \mathrm{~h}$. (A) IL-6, (B) IL$1 \beta$, and (C) TNF- $\alpha$ production were determined by ELISA. The data represent the mean \pm SD of quadruplicate experiments. ${ }^{*} p<0.05,{ }^{* *} p<0.01$ versus LPS alone. IL- $6: \mathrm{IC}_{50}=1.49 \mathrm{mM}$, IL$1 \beta: \mathrm{IC}_{50}=1.44 \mathrm{mM}$

lincomycin was $71.7 \%$ for IL-6, $64.3 \%$ for IL-1 $\beta$, and $36.8 \%$ for TNF- $\alpha$. 


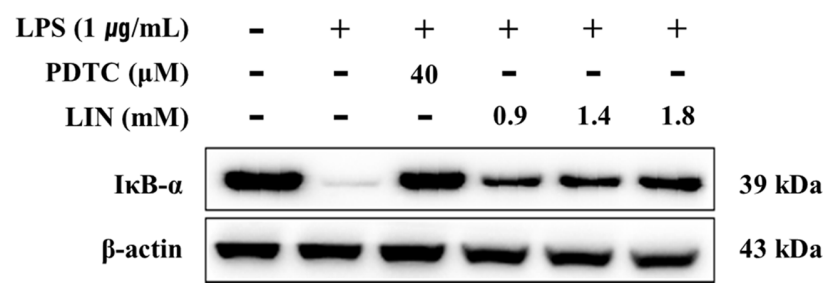

Fig. 6. Effect of lincomycin on degradation of IKB- $\alpha$ in LPS stimulated RAW 264.7 cells. RAW 264.7 cells $\left(1.0 \times 10^{6}\right.$ cells/ $\mathrm{ml})$ were stimulated with LPS $(1 \mu \mathrm{g} / \mathrm{ml})$ in the presence of lincomycin $(0.9,1.4$, or $1.8 \mathrm{mM})$, or PDTC $(40 \mu \mathrm{M})$ for $20 \mathrm{~min}$. Whole cell lysates $(30 \mu \mathrm{g})$ were prepared, and proteins were separated by $4-12 \%$ Bis-Tris NuPAGE gel electrophoresis, and expression of IKB- $\alpha$ and $\beta$-actin were determined by western blotting. $\beta$ actin served as a loading control. PDTC: NF- $\mathrm{KB}$ inhibitor.

\section{Effect of LIN on the NF- $\kappa$ B pathway in RAW264.7 cells}

The production of pro-inflammatory cytokines and iNOS expression is regulated by the major transcription factor NF- $\kappa \mathrm{B}$ [26]. In the present experiments, we investigated the cytoplasmic inhibition of I $\kappa \mathrm{B}-\alpha$ degradation in order to confirm the mechanism of NF- $\kappa$ B and I $\mathrm{B}-\alpha$ activity. When RAW 264.7 cells were stimulated with LPS, cytoplasmic I $\kappa$ B- $\alpha$ decreased to a maximum at $20 \mathrm{~min}$, and increased again by $30 \mathrm{~min}$ (data not shown). To confirm whether LIN affects the inhibition of I $\mathrm{B}-\alpha$ degradation, PDTC (40 $\mu \mathrm{M}), \mathrm{NF}-\kappa \mathrm{B}$ inhibitor, and LIN were pretreated for $2 \mathrm{~h}$, then treated with LPS, and proteins were obtained after $20 \mathrm{~min}$ to perform western blotting. In the PDTC-treated group, the degradation of I $\mathrm{B}-\alpha$ was inhibited, compared to the LPS-treated group, and LIN also significantly inhibited the degradation of IкB- $\alpha$, as compared with the LPS-treated group (Fig. 6).

\section{Effect of LIN on the MAPKs pathway in RAW264.7 cells}

On the other hand, activation of NF- $\mathrm{BB}$ is known to be regulated by kinases such as MAPKs and PI3K/Akt (PKB) [27]. Thus, the effect of LIN on phosphorylation of MAPKs affecting NF- $\mathrm{B}$ activity was evaluated. As shown in Fig. 7, In RAW 264.7 cells induced by LPS, phosphorylation of JNK decreased by LIN treatment in a dose dependent manner.

These results indicated that LIN exhibits anti-inflammatory activity by regulating phosphorylation of IкB- $\alpha$, as well as by phosphorylation of NF- $\mathrm{B}$ upstream signaling molecules.

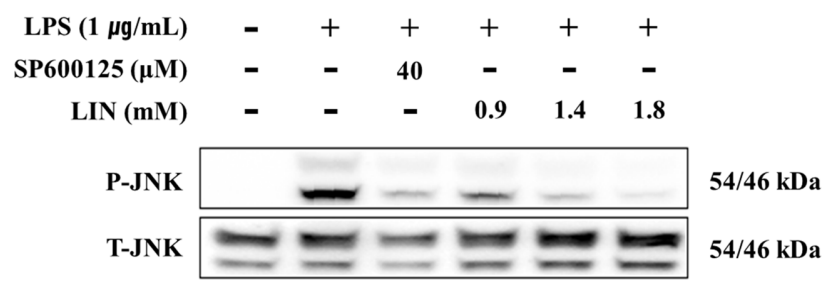

Fig. 7. Effect of lincomycin on the phosphorylation of P-JNK in LPS-stimulated RAW 264.7 cells. RAW 264.7 cells $\left(1.0 \times 10^{6}\right.$ cells $/ \mathrm{ml})$ were stimulated with LPS $(1 \mu \mathrm{g} / \mathrm{ml})$ in the presence of lincomycin $(0.9,1.4$, or $1.8 \mathrm{mM})$, or SP600125 (40 $\mu \mathrm{M})$, for $20 \mathrm{~min}$. Whole cell lysates $(30 \mu \mathrm{g})$ were prepared, and proteins separated by $4-12 \%$ Bis-Tris NuPAGE gel electrophoresis, and expression of P-JNK and T-JNK were determined by western blotting. SP600125: JNK inhibitor.

\section{Discussion}

Although the extensive use of antibiotics has caused a variety of side effects, some of these anti-biotics may have a further purpose in the vast field of medicine. Previous studies have confirmed that some antibiotics have anti-inflammatory properties. Therefore we tried to confirm anti-inflammatory effects on classic antibiotics such as lincomycin by studying the mechanism of inflammation at the protein level.

These results demonstrated that the production and expression of inflammation mediators, such as NO and PGE2, as well as pro-inflammatory cytokines, are strongly inhibited by LIN in LPS-stimulated RAW 264.7 cells. This inhibitory effect of LIN has been shown to be related to inactivation of the NF- $\mathrm{B}$ pathway by inhibiting the degradation of I $\mathrm{B}-\alpha$. In addition, LIN was found to affect inhibition of phosphorylation of JNK, involved in the upstream signaling pathway of $\mathrm{NF}-\kappa \mathrm{B}$ activation (results summarized in Fig. 8).

Based on the results of this experiment, LIN, which has narrow utilization, can be an important tool for the study of macrophage-mediated inflammatory responses. In order to study the relationship between more antiinflammatory and antibiotics, it may be needed for evaluating effects by structural differences in antibiotics. Nevertheless, these results can be presented as an effective therapeutic regimen for various kinds of acute and chronic inflammatory diseases, including skin disorders, and suggests the possibility of LIN being used in cosmetics or medicines. 


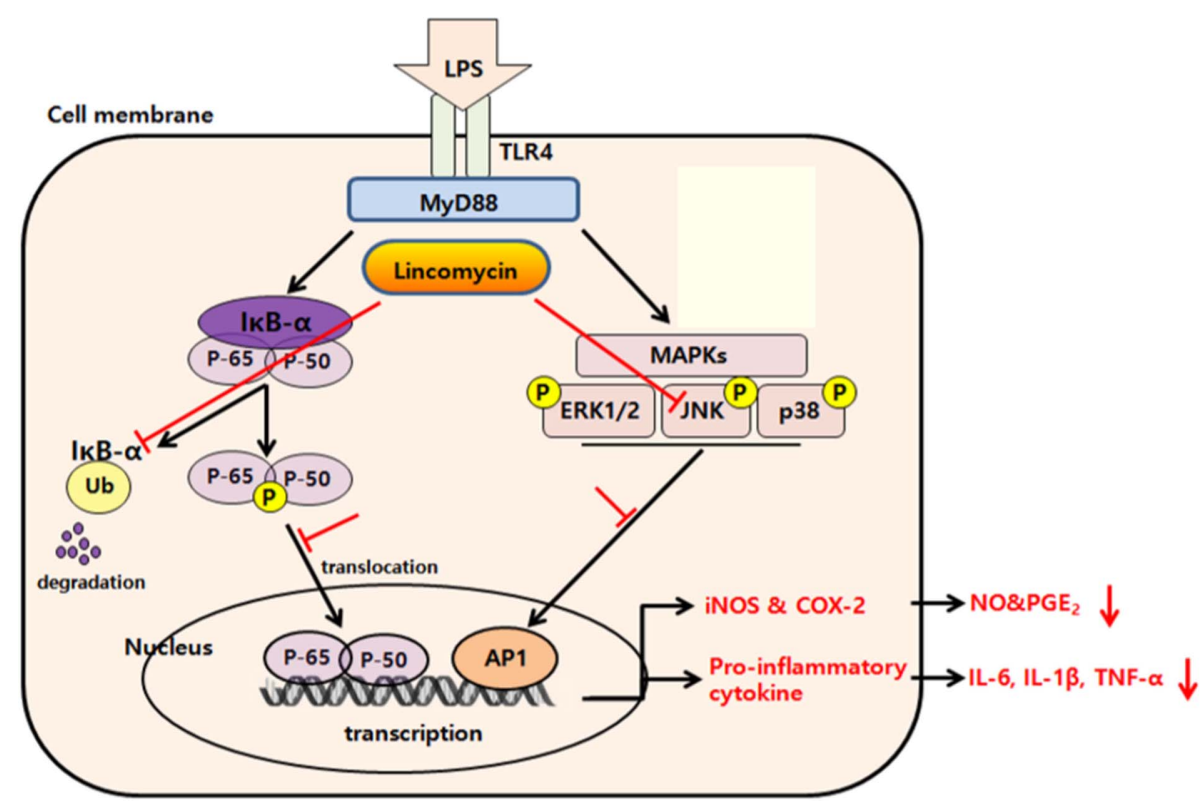

Fig. 8. Model of anti-inflammatory mechanism of lincomycin and signaling pathways involved in LPS-stimulated RAW 264.7 cells.

\section{Acknowledgments}

This work was supported by the 2019 education, research and student guidance grant funded by Jeju National University.

\section{Conflict of Interest}

The authors have no financial conflicts of interest to declare.

\section{References}

1. Udommethaporn S, Tencomnao T, McGowan EM, Boonyaratanakornkit V. 2016. Assessment of anti-TNF- $\alpha$ activities in keratinocytes expressing inducible TNF- $\alpha$ : A novel tool for anti-TNF- $\alpha$ drug screening. PLoS One 11: e0159151.

2. Lapara NJ 3rd, Kelly BL. 2010. Suppression of LPS-induced inflammatory responses in acrophages infected with Leishmania. J. Inflamm (Lond). 7: 8.

3. Zhang X, Li N, Shao H, Meng Y, Wang L, Wu Q, et al. 2016. Methane limit LPS-induced NF- $\kappa B / M A P K s$ signal in macrophages and suppress immune response in mice by enhancing PI3K/AKT/GSK-3 $\beta$ mediated IL-10 expression. Sci. Rep. 11: 6 .

4. Gao HM, Liu B, Zhang W, Hong JS. 2003. Novel anti-inflammatory therapy for Parkinson's disease. Trends Pharmacol. Sci. 24: 395401.

5. Copeland S, Warren HS, Lowry SF, Calvano SE, Remick D. 2005. Acute inflammatory response to endotoxin in mice and humans. Clin. Diagn. Lab. Immunol. 12: 60-67.

6. Roos-Engstrand E, Wallin A, Bucht A, Pourazar J, Sandström T,
Blomberg A. 2005. Increased expression of p38 MAPK in human bronchial epithelium after lipopolysaccharide exposure. Eur. Respir. J. 25: 797-803.

7. Soromou LW, Zhang Z, Li R, Chen N, Guo W, Huo M, et al. 2012. Regulation of inflammatory cytokines in lipopolysaccharidestimulated RAW 264.7 murine macrophage by 7-0-methylnaringenin. Molecules 17: 3574-3585.

8. Yang G, Lee K, Lee M, Ham I, Choi HY. 2012. Inhibition of lipopolysaccharide-induced nitric oxide and prostaglandin $\mathrm{E}_{2}$ production by chlo-roform fraction of Cudrania tricuspidata in RAW 264.7 macrophages. BMC Complement. Altern. Med. 12: 250.

9. Gomez I, Foudi N, Longrois D, Norel X. 2013. The role of prostaglandin $E_{2}$ in human vascular inflammation. Prostaglandins Leukot. Essent. Fatty Acids 89: 55-63.

10. Lee HJ, Oh TH, Yoon WJ, Kang GJ, Yang EJ, Park SS, et al. 2008. Eutigoside $\mathrm{C}$ inhibits the production of inflammatory mediators (NO, PGE 2 IL-6) by down-regulating NF-KB and MAP kinase activity in LPS-stimulated RAW 264.7 cells. J. Pharm. Pharmacol. 60: 917-924.

11. Kim JB, Han AR, Park EY, Kim JY, Cho W, Lee J, et al. 2007. Inhibition of LPS-induced iNOS, COX-2 and cytokines expression by poncirin through the NF-KB inactivation in RAW 264.7 macrophage cells. Biol. Pharm. Bull. 30: 2345-2351.

12. Lawrence T. 2009. The nuclear factor NF-KB pathway in inflammation. Cold Spring Harbor Perspect. Biol. 1: a001651.

13. Tak PP, Firestein GS. 2001. NF-KB: a key role in inflammatory diseases. J. Clin. Invest. 107: 7-11.

14. Yeom M, Kim JH, Min JH, Hwang MK, Jung HS, Sohn Y. 2015. Xanthii fructus inhibits inflammatory responses in LPS-stimulated RAW 264.7 macrophages through suppressing NF-KB and JNK/ 
p38 MAPK. J. Ethnpharmacol. 24: 394-401.

15. Fang $H$, Pengal RA, Cao X, Ganesan LP, Wewers MD, Marsh CB, et al. 2004. Lipopolysaccharide-induced macrophage inflammatory response is regulated by SHIP. J. Immunol. 173: 360-366.

16. Frazier WJ, Xue J, Luce WA, Liu Y. 2012. MAPK signaling drives inflammation in LPS-stimulated cardiomyocytes: the route of crosstalk to G-protein-coupled receptors. PLoS One. 7:e50071.

17. Neuder LE, Keener JM, Eckert RE, Trujillo JC, Jones SL. 2009. Role of p38 MAPK in LPS induced pro-inflammatory cytokine and chemokine gene expression in equine leukocytes. Vet. Immunol. Immunopathol. 294: 192-199.

18. MacLeod AJ, Ross HB, Ozere RL, Digout G, van Rooyen CE. 1964. Lincomycin: A new antibiotic active against Staphylococci and other gram-positive cocci: Clinical and Laboratory Studies. Can. Med. Assoc. J. 14: 1056-1060.

19. Duncan IB, Jeans B. 1965. Lincomycin in hospital practice. Can. Med. Assoc. J. 93 685-691.

20. Imai Y, Sato S, Tanaka Y, Ochi K, Hosaka T. 2015. Lincomycin at subinhibitory concentrations potentiates secondary metabolite production by Streptomyces spp. Appl. Environ. Microbiol. 81: 3869-3879.

21. Hall IH, Schwab UE, Ward ES, Ives TJ. 2003. Effects of moxifloxacin in zymogen A or S. aureus stimulated human THP-1 monocytes on the inflammatory process and the spread of infection. Life Sci. 73: $2675-2685$.
22. Nakano T, Hiramatsu K, Kishi K, Hirata N, Kadota J, Nasu M. 2003. Clindamycin modulates inflammatory-cytokine induction in lipopolysaccharide-stimulated mouse peritoneal macrophages. Antimicrob. Agents Chemother. 47: 363-367.

23. Ulich TR, Yin S, Remick DG, Russell D, Eisenberg SP, Kohno T. 1993. Intratracheal administration of endotoxin and cytokines. IV. The soluble tumor necrosis factor receptor type I inhibits acute inflammation. Am. J. Pathol. 142: 1335-1338.

24. Leigh WK, Firoz R, Richard DH, Jr., Rebecca CG, Suzanne MM. 1998. Effect of lipopolysaccharide and inflammatory cytokines on interleukin-6 production by healthy human gingival fibroblasts. Infect. Immun. 66: 608-614.

25. Ramana KV, Fadl AA, Tammali R, Reddy AB, Chopra AK, Srivastava SK. 2006. Aldose reductase mediates the lipopolysa-ccharideinduced rele-ase of inflammatory mediators in RAW264.7 murine macrophages. J. Biol. Chem. 281: 33019-33029.

26. Vo VA, Lee JW, Kim JY, Park JH, Lee HJ, Kim SS, et al. 2014. Phosphorylation of Akt mediates anti-Inflammatory activity of 1-pCoumaroyl $\beta$-D-Glucoside against lipopolysaccharide-induced inflammation in RAW264.7 Cells. Korean J. Physiol Pharmacol. 18: 79-86.

27. Xu X, Li H, Hou X, Li D, He S, Wan C, et al. 2015. Punicalagin induces Nrf2/HO-1 expression via upregulation of PI3K/AKT pathway and inhibits LPS-induced oxidative stress in RAW264.7 macrophages. Mediators Inflamm. 2015: 380218. 